[ 사 례 연구 ]

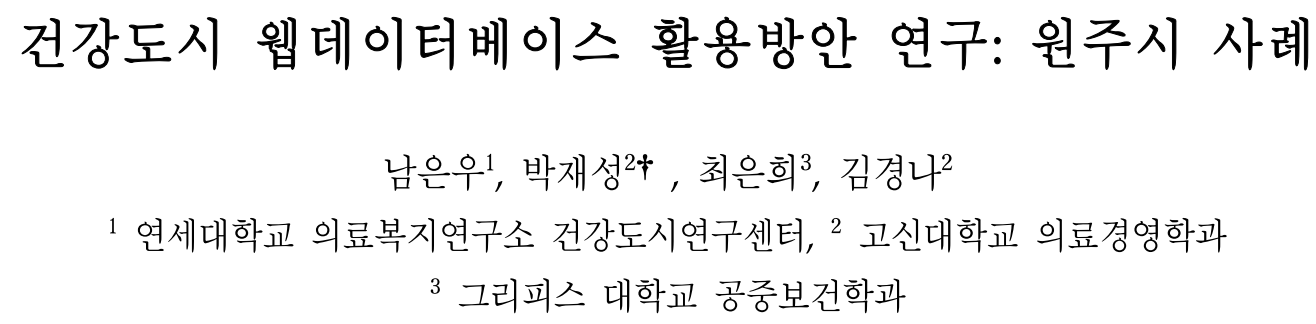

\title{
A Study on the Application of Web Database for Healthy City Wonju
}

\author{
Eun-Woo Nam ${ }^{1}$, Jae-Sung Park ${ }^{2 \dagger}$, Eun-Hee Choe ${ }^{3}$, Gyeong-Na Kim ${ }^{2}$ \\ ${ }^{1}$ Healthy City Research Center, Institute of Health and Welfare, Yonsei University, Wonju \\ ${ }^{2}$ Dept. of Health Care Adminstration, Kosin University, Pusan \\ ${ }^{3}$ Griffith University School of Public Health, Australia, PhD candidate.
}

\begin{abstract}
$<$ Abstract $>$
The purpose of this study is to introduce the web database for healthy city Wonju that contains healthy city indicators and materials. It has provided diverse information to public officers who are working on healthy city projects and citizens for monitoring and evaluating the projects, effectively. The web database was made on 2006 and was updated on 2009. The new Web database system was designed for supporting that the staffs of healthy city can manage all data update by themselves.

The new Web database encompasses more recent information about health city projects. After identifying users' needs and reasons for modifying the fields of data, we added new indicators to the Web database. Some redundant indicators were deleted based on users' requests. The Web database quality evaluations were peformed by using 13 quality evaluations constructs. Through all 13 constructs, less than $20 \%$ of study subjects felt that it did not satisfy their needs or expectations.

Well developed and verified contents of the Web database for healthy city are very essential and important. The database makes healthy city projects alive by managing and sharing healthy city related data and indicators effectively.
\end{abstract}

Key Words : Web Database, Healthy City, Healthy City Indicator 


\section{I. 서론}

건강도시는 1986년 11월 캐나다에서 개최된 국 제건강증진회의에서 선언된 오타와 헌장의 철학과 건강에 대한 접근법인 사회적-정치적 변화를 통 해서 지역사회 인구집단의 건강수준을 향상시킬 수 있다는 개념을 출발하였다. 특히 지역주민의 건 강수준 향상을 위한 건강한 환경 조성에 지방자치 단체의 역할이 중요하다는 개념을 강조한다. 국내 에서는 1996년 과천시의 시범사업으로 시작되어, 2009년 현재 대한민국건강도시협의회의 정회원으 로 가입한 지자체가 총 39개, 준회원으로 가입한 단체가 8개로 활발히 활동하고 있다[1].

효과적인 건강도시 구축을 위해 우선 필요한 것 은 타당성과 신뢰성을 갖춘 건강도시지표의 개발 과 활용은 필수적인 영역이라 할 수 있다. 또한 건 강도시지표에 대한 체계적인 모니터링을 실시할 수 있다면, 확대되고 있는 건강도시사업의 효과를 제고시킬 수 있을 것이다. 또한 보다 객관적이고 과학적 증거에 근거한 사업을 계획하고 평가할 수 있고, 축적된 자료들은 시계열적인 변화 및 타 도 시와의 비교 평가를 가능하게 할 수 있다면 보다 효과적으로 건강도시를 구축할 수 있는 기반을 제 공한다고 할 수 있을 것이다[2][3][4]. 따라서 지역 사회 차원에서 각 지역의 건강도시사업을 모니터 링하고 평가하기 위하여 집약된 형태의 데이터베 이스에 대한 필요성이 요구된다고 할 수 있다.

원주시는 2006년 건강도시사업 5개년 계획을 수립하기 이전인 2005년에 원주시 건강도시 데이 터베이스 구축 계획을 수립하여 2006년에 건강도 시 사업을 위한 웹 데이터베이스를 구축하여 운영 하였다. 그러나 기간이 경과함에 따라 건강도시정 보에 대한 수요가 증가하고 건강도시 사업의 환경 변화에 따른 지표의 수정이 필요하게 되었고, 또한 건강도시 정보 이용자의 요구를 적극 수용할 필요 성이 제기되었다.
2009년 원주시는 건강도시와 관련 된 새로운 지 표 자료의 수집 및 정리를 보다 효율적으로 관리 하고, 원주시 건강도시 수준의 시계열적 변화 및 현황 파악할 수 있도록 건강도시 홈페이지와 연동 하여 건강도시 데이터베이스를 새롭게 구축하였다. 새로운 웹 데이터베이스는 건강도시사업을 보다 효율적, 효과적으로 수행할 수 있도록 다양한 곳에 원천을 두고 있는 모든 자료를 보다 요약- 통합된 정보를 생산하게 할 수 있게 하며, 모든 건강도시 사업의 기획, 실행 및 평가에 있어 보다 근거에 중 심한 사업관리를 실현할 수 있게 할 것이다.

\section{II. 연구방법}

1. 연구프로세스

원주시 건강도시 데이터베이스는 2006년 1월에 구축되어 약 3 년간 운영하였다. 이 사례보고는 2009까지 3년간 운영된 기존의 웹 데이터베이스를 바뀐 새로운 직면된 건강도시 사업의 환경에 대처 하기 위해 웹 데이터베이스를 업데이트하였다. 이 를 위해 2009년 3월에 이용자료 요구도를 분석하 였고, 업데이트를 한 이후 시범운영(test run)을 하 였다. 이후 2009년 6월에 업데이트 사후조사를 실 시하여, 데이터베이스의 평가를 위하여 12 개 특성 을 평가하였다.

\section{2. 조사도구 개발}

건강도시 데이터베이스 업데이트를 위한 설문지 는 국내외 선행연구[5][6][7][9]10][11][12]를 바탕으 로 설문지를 개발하였다. 건강도시 웹 데이터베이 스의 평가를 위하여 데이터베이스에 대한 총 12 개 특성에 대하여 평가하는 조사도구인 설문지를 개 
발하였고, 각 특성의 정의는 다음과 같다.

- 정확성(Accuracy): 데이터베이스가 올바른 결과 를 출력할 수 있는 정도

- 최신성(Currentness): 데이터베이스의 정보가 정기적으로 갱신되는지에 대한 정도

- 일관성(Consistency): 의미, 표현, 방법이 일률 적, 동일적인 성질

- 포괄성(Inclusiveness): 데이터베이스가 찾으려 는 주제에 관련된 자료를 포함하는 정도

- 권위(Authority): 데이터베이스의 내용이 가지 는 권위와 신뢰의 정도

- 유일성(Uniqueness): 다른 곳에서 찾을 수 없 는 독특한 정보를 갖고 있는 정도

- 신속성(Speediness): 검색이 이루어지는 속도

- 사용지원성(Support for use): 지정된 업무 수 행에 필요한 기능이 존재하며, 기능이 적절한 정도

- 유형성(Tangibility): 정보를 정확하고 편리하게 사용할 수 있도록 디자인된 정도

- 이해용이성(Understanding): 사용자의 데이터 베이스 개념과 응용성 인식에 필요한 노력의 정도

- 사용용이성(Ease of use): 사용을 위한 노력과 그러한 사용에 대한 개개인의 심사와 관련된 속성

- 효과성(Effectiveness): 데이터베이스가 궁극적 으로 미칠 것으로 예상되는 영향

\section{3. 요구도 조사}

건강도시 정보 이용자의 요구를 파악하여 이용 효율성이 높은 건강도시 데이터베이스로 업데이트 하고자 사전조사를 실시하였다. 건강도시 정보 이 용자 조사는 원주시청과 원주시 보건소의 직원을 대상으로 하여 건강도시 데이터베이스 업데이트
전인 2009년 3월에 실시하였다. 훈련된 조사요원이 개발된 설문지를 이용하여 면접조사를 실행하였다. 조사내용은 정보 이용자의 일반적 특성, 데이터베 이스의 이용 현황, 평가, 만족도, 개선요구사항 등 이었으며, 원주시 건강도시 데이터베이스 담당자 조사를 병행하였다.

원주시 건강도시 데이터베이스 담당자 조사는 원주시 건강체육과 건강도시팀 3 인을 대상으로 데 이터베이스 개선요구사항 등에 대하여 2009년 3월 부터 4월까지 심층면접조사(in-depth interview) 형 태로 3회 실시하였다.

\section{4. 건강도시 웹데이터베이스 재설계}

1) 건강도시 웹데이터베이스의 기술적 환경

건강도시 정보를 수집하여 입력한 $\mathrm{DB}$ 와 웹사이 트를 연동하는 형식을 취하는 브라우즈 확장 방식 을 이용하여 구축하였다. 시스템 구축에 사용된 도 구(tool)는 HTML과 Java Script, 브라우즈와 $\mathrm{DB}$ 의 연동을 위해서는 $\mathrm{ASP}$ 를 사용하였다. 그리고 데이 터베이스관리시스템은(DBMS)는 MS-Access를 사용 하였다. 기존의 웹 $\mathrm{DB}$ 에 대한 평가를 바탕으로 화 면 구성 및 인터페이스를 보다 사용이 편리하고 이해하기 쉽도록 개선을 시도하였다.

2) 건강도시지표 및 건강도시 관련 새로운 자 료의 수집 및 선정

본 연구에서는 세계보건기구에서 건강도시지표 로 제시하고 있는 인구규모 및 동태 등 7개 영역 (focus areas)으로 구분된 항목에 의거하여, 건강도 시지표를 보완하고자 하였다. 건강도시지표 보완은 요구도조사에서 파악된 건강도시지표에 대한 요구 도 분석, 건강도시지표에 대한 최신 보고서 및 기 타 문헌의 고찰을 통해 데이터베이스에 필요한 건 강도시지표를 재구성하였다. 업데이트되는 웹데이 터베이스에서는 건강도시지표 이외의 건강도시관 
련 사업계획서, 각종 보고서 등의 자료들을 제공하 였다.

\section{5. 사후조사}

업데이트된 원주시 건강도시 데이터베이스의 개 선 정도를 평가하고자 시범운영 기간 중에 원주시 및 원주시 보건소 공무원, 원주시내 보건학 전공 학생을 대상으로 사후조사를 실시하였다. 조사는 훈련된 조사요원에 의한 방문 면접조사로 실시되 었으며, 업데이트된 데이터베이스에 대한 12 개 개 념에 대한 적합성을 조사하였다. 최종 수거된 설문 지 192부를 대상으로 업데이트된 웹 데이터베이스 에 대한 평가 분석을 수행하였다.

\section{III. 연구결과}

\section{1. 요구도조사 결과}

1) 건강도시 정보 이용자 대상 조사 결과 원주시 건강도시 데이터베이스 이용자를 대상으 로 요구도 조사를 실시한 결과, 응답자의 인구사회 학적 특성을 보면 다음과 같다.

<표 1> 요구도조사 응답자의 인구학적 특성

\begin{tabular}{|c|c|c|c|}
\hline 분류 & 항목 & 명 & $\%$ \\
\hline \multirow[t]{4}{*}{ 연령 } & 29세 이하 & 19 & 18.6 \\
\hline & 30 39세 & 39 & 38.2 \\
\hline & 40 49세 & 31 & 30.4 \\
\hline & 50세 이상 & 13 & 12.7 \\
\hline \multirow[t]{3}{*}{ 성별 } & 남 & 60 & 58.8 \\
\hline & 여 & 42 & 41.2 \\
\hline & 계 & 102 & 100.0 \\
\hline
\end{tabular}

응답자의 연령별 분포를 살펴보면, 30 39세가 39명(38.2\%)으로 가장 많았고, 그 다음으로는 40 49세가 31명(30.4\%), 29세 이하인 경우는 19명 $(18.6 \%), 50$ 세 이상인 경우는 13 명(12.7\%)의 순이었 다. 남자가 60 명 $(58.8 \%)$ 으로 여자 42 명 $(41.2 \%)$ 보다 많았다<표 1>.

데이터베이스에 대한 인지 및 업데이트 요구에 대한 조사결과를 살펴보면, 일반적인 데이터베이스 인지도에서는 '모름'으로 응답한 경우와 '알고 있 음'으로 응답한 경우가 각각 51 명 $(50.0 \%)$ 이었다. 모 르고 있는 것으로 응답한 경우가 절반을 차지하는 것으로 조사되어서 이들을 대상으로 데이터베이스 에 대한 홍보나 교육이 필요한 것으로 생각된다 <표 2>

<표 2> 웹데이터베이스에 대한 인지 및 업데이트 요구도

\begin{tabular}{|c|c|c|c|}
\hline 분 류 & 항목 & 명 & $\%$ \\
\hline \multirow{2}{*}{ 데이터베이스 인지도 } & 모름 & 51 & 50.0 \\
\hline & 알고 있음 & 51 & 50.0 \\
\hline \multirow{3}{*}{$\begin{array}{l}\text { 데이터베이스 개선·구축 } \\
\text { 의 필요성 }\end{array}$} & 필요 없음 & 5 & 4.9 \\
\hline & 보통 & 25 & 24.5 \\
\hline & 필요함 & 72 & 70.6 \\
\hline \multirow{4}{*}{ 바람직한 업데이트 주기 } & 1 & 69 & 67.6 \\
\hline & 2 & 13 & 12.7 \\
\hline & 3 & 12 & 11.8 \\
\hline & $4 \sim$ & 8 & 7.9 \\
\hline \multirow{7}{*}{ 바람직한 자료 제공 기간 } & 1 & 27 & 26.5 \\
\hline & 2 & 13 & 12.7 \\
\hline & 3 & 18 & 17.6 \\
\hline & 4 & 2 & 2.0 \\
\hline & 5 & 21 & 20.6 \\
\hline & $10 \sim$ & 21 & 20.6 \\
\hline & 계 & 102 & 100.0 \\
\hline
\end{tabular}

데이터베이스 개선 · 구축의 필요성에 대하여는 '필요함'에 72 명 $(70.6 \%)$, '보통'에 25 명 $(24.5 \%)$ 이 응 답하여서, 대부분의 응답자가 필요성을 인식하는 것으로 분석되었다. 업데이트 주기에 대하여 ' 1 년' 69 명 $(67.6 \%)$, '2년' 13 명 $(12.7 \%)$ 의 순으로 응답하여 
서, 절반 이상의 대상자가 매년 업데이트하는 것을 원하는 것으로 분석되었다. 건강도시정보 데이터베 이스에서 제공할 자료의 기간에 대하여 1 년간의 연속된 자료 제공이 필요한 것으로 응답한 경우가 27 명 $(26.5 \%)$ 으로 가장 많았고, 다음으로는 5년간의 자료 제공이 필요한 것으로 응답한 경우가 21명 (20.6\%)으로 많았다.

필요한 건강도시정보로 각종 자료에는 국내외 건강도시 세부현황 및 추진사업, 국내외 건강도시 주요 $\mathrm{DB}$ 비교, 국내 건강도시별 각종자료, 시군별 건강증진 정책, 건강도시 추진정책의 추가가 필요 한 것으로 응답하였다. 또한 건강도시지표에서는 원주시 통계연보의 지속적인 사용, 사망원인별 사 망률이 필요한 것으로 응답하였다.

2) 건강도시 데이터베이스 담당자 대상 면담 조사 결과

원주시의 건강도시 데이터베이스 담당자를 대상 으로 면담조사를 실시한 결과, 원주시에서 자체적 으로 데이터를 업데이트하고, 자료의 업로드가 가 능하도록 할 필요가 있는 것으로 응답하였다. 2006 년도에 구축된 데이터베이스는 원주시청에서 데이 터 업데이트하기에 불편함이 있었던 것이 언급되 었다.

또한 건강도시정보에 대하여는 데이터 생산 및 접근이 용이한 지표로 조정하는 것이 필요한 것으 로 응답하였다. 구체적으로는 시민들이 간명하게 이해할 수 있는 “원주의 하루"(하루당 출생, 사망, 이사 오는 사람, 이사 가는 사람, 결혼, 이혼, 자동 차 등록, 급수량, 화재 발생건수, 전력 사용량, 건 축허가, 쓰레기 발생량, 교통사고 발생건수 등) 추 가에 대한 요구가 있었으며, 이는 매년 데이터 생 산이 되고 있으므로 업데이트가 용이하다는 장점 이 있다.
2. 각종자료, 건강도시지표 및 건강도시중점 관리지표의 보완

원주 건강도시 데이터베이스는 각종 자료, 건강 도시지표, 건강도시중점관리지표로 구분하여 업데 이트되었다.

\section{1) 각종자료의 보완}

각종자료는 세계 각국 자료, 우리나라 자료, 원 주시 자료[8], 출판물, 각종자료, 건강증진관련 법 령으로 분류되어 업데이트되었으며, 제 3 차 건강도 시연맹 국제회의 자료, 새국민건강증진종합계획, 2006년 이후 각 년도별 건강도시사업 종합시행계 획과 종합추진상황 보고서, 제 4 기 지역보건의료계 획, 2005년 이후 각 년도별 건강증진사업계획서를 추가하였다.

또한 원주시에 대한 보건복지 관련 분야의 최신 연구자료를 추가하여 건강도시사업에 도움이 되도 록 하였으며, 2007 원주시 건강도시 자문위원회 위 원 명단과 최근 건강증진관련 법령을 업데이트하 여 건강도시 관련 정보를 쉽게 찾을 수 있도록 하 였다.

2) 건강도시지표 및 건강도시중점관리지표의 보완

이 연구의 건강도시지표는 WHO City health profiles의 9가지 지표영역[14]을 기준으로 하였다. 2006년도에 개발된 건강도시중점관리지표는 총 9 개 영역의 34개 지표였으나, 이번 2009년에는 국내 외 새로운 건강도시지표와 요구도조사 결과를 참 고하여, 건강도시중점관리지표를 8개 영역 29개 지 표로 변경하였다. 건강도시지표는 총 7 개 영역의 107 개 지표에서 80 개 지표로 변경하였다.

변경한 이유는 2007년 이후 약 2년간 건강도시 중점관리지표를 사용한 결과, 지속적인 모니터링과 자료 생성에 어려움이 있었기 때문이다. 또한, 매 
년 질병관리본부(KCDC)에서 실시하게 된 지역건 강조사에서 생성되는 자료를 참고하여 건강도시사 업에 유용한 지표로 변경하였다. 그리고 최근 건강 도시와 관련하여 중요성이 커지고 있는 지표를 추 가하였다. 따라서, 이번에 업데이트된 원주시 건강 도시 데이터베이스의 특징은 매년 데이터 생산이
되고 있으며, 데이터에 대한 접근이 용이하고, 전 국 비교가 가능하고, 원주시 통계연보 및 지역사회 건강조사에서 주기적으로 제공될 수 있는 지표를 중심으로 건강도시중점관리지표를 변경한 것이다 <표 3>.

<표 3> 건강도시중점지표의 개정 및 이유

\begin{tabular}{|c|c|}
\hline 추가지표명 & 이유 \\
\hline 주관적 스트레스 인지율 & $\begin{array}{l}\text { 스트레스 관리의 중요성 증가 } \\
\text { 지역사회건강조사 데이터의 매년 생산 }\end{array}$ \\
\hline 이산화탄소 & 지구온난화로 인한 관리의 중요성 증가 \\
\hline 고혈압 평생의사진단 유병률 & 만성질환 관리의 중요성 증가 \\
\hline 당뇨병 평생의사진단 유병률 & 만성질환 관리의 중요성 증가 \\
\hline 변경지표명 & 이유 \\
\hline 10대 주요사인별 사망률 $\rightarrow$ 주요사인별 사망률 & $\begin{array}{l}\text { 인구집단의 건강수준 파악을 위한 대표적 지표 } \\
\text { 요구도조사 결과에 따른 요구 반영 }\end{array}$ \\
\hline 흡연율 $\longrightarrow$ 흡연율(남) & $\begin{array}{l}\text { 여성보다 높은 남성의 흡연율을 중점적으로 관리 } \\
\text { 지역사회건강조사시 매년 생산 }\end{array}$ \\
\hline 음주율 $\longrightarrow$ 고위험음주율 & $\begin{array}{l}\text { 건강에 유해한 영향이 큰 것으로 보고된 고위험음주율을 집중 관리 } \\
\text { 지역사회건강조사시 매년 생산 }\end{array}$ \\
\hline 운동실천율 $\rightarrow$ 걷기운동실천율 & 지역사회건강조사시 매년 생산 \\
\hline $\mathrm{BMl} \rightarrow$ 비만인구율 & $\begin{array}{l}\text { 각종 만성질환 예방을 위하여 관리되어야 하는 주요 생활양식 지표 } \\
\text { 지역사회건강조사시 매년 생산 }\end{array}$ \\
\hline 의료급여수급자비율 $\longrightarrow$ 국민생활보장수급자비율 & 매년 데이터가 생산 되고 있으며 사용이 용이함 \\
\hline 보건교육실시율 $\rightarrow$ 보건교육건수 & 데이터 산출의 용이성 \\
\hline 삭제지표명 & 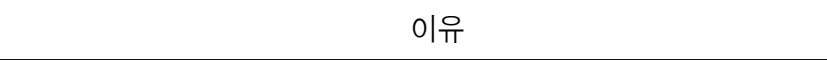 \\
\hline 영아사망률 & 정기적인 데이터 산출의 어려움 \\
\hline 하루 식사 횟수 & 정기적인 데이터 산출의 어려움 \\
\hline 주택 보급률 & 정기적인 데이터 산출의 어려움 \\
\hline 주거 만족도 & 정기적인 데이터 산출의 어려움 \\
\hline 실당 사람 수 & 정기적인 데이터 산출의 어려움 \\
\hline 실업률 & 정기적인 데이터 산출의 어려움 \\
\hline 지역별 앵겔지수 & 정기적인 데이터 산출의 어려움 \\
\hline 인터넷 보급율 & 정기적인 데이터 산출의 어려움 \\
\hline
\end{tabular}


영아사망률, 하루 식사 횟수, 주택 보급률, 주거 만족도, 실당 사람 수, 실업률, 지역별 앵겔지수, 인터넷 보급률을 제외하였고, 주관적스트레스인지 율, 이산화탄소, 고혈압평생의사진단유병률, 당뇨병 평생의사진단유병률을 새로 추가하여 다음과 같이 건강도시중점관리지표를 최종 선정하였다.

인구규모 및 동태

- 인구밀도

- 총인구수

- 5세 계급 연령별 성별 인구수 건강수준

- 조출생률

- 표준화사망률

- 주요사망원인

생활양식

- 흡연율(남)

- 고위험음주율

- 걷기운동실천율

- 비만인구율

- 주관적스트레스인지율

사회경제적 여건

- 학교수대비인구수

- 범죄발생률

- 공연시설수대비인구수

- 체육시설수대비인구수

물리적 환경

- 오존

- 이산화탄소

- 생물학적 산소 요구량

- 인구 천명당 쓰레기 배출량

- 소음도

- 일인당 공원면적

불평등

- 국민생활보장수급자비율

물리사회적 하부구조
- 도로포장률

- 보육시설수

공중보건정책 및 서비스

- 암건강검진율

- 예방접종건수

- 보건교육건수

- 고혈압평생의사진단유병률

- 당뇨병평생의사진단유병률

3. 원주시 건강도시 웹 데이터베이스 (Web-Database)의 구성도

본 건강도시 지표관리를 위한 웹 데이터베이스 의 전체 환경구성도(context diagram)은 다음 <그 림 1>과 같다. Healthy City Web Data Base Center를 중심으로 각종 정보를 집적하여 사용자 의 요구에 맞게 활용하도록 하였다. 웹상에서 건강 도시를 위한 정보를 공유할 수 있도록 한 것은 건 강도시관련 공무원과 일반시민들도 손쉽게 웹사이 트를 방문하는 것만으로도 웹 $\mathrm{DB}$ 에 접근이 가능하 도록 하여 사용자의 편의성과 정보의 활용성을 높 이고자 한 것이다.

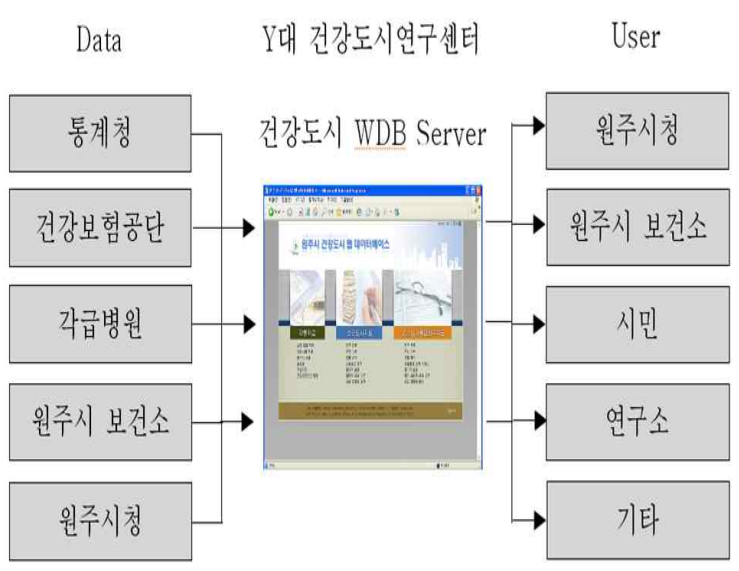

<그림 1> 원주 건강도시 웹데이터베이스의 구성 및 데이터 흐름

<그림 2>과 <그림 3>와 같이 초기화면에서와 
같이 웹데이터베이스는 각종자료, 건강도시지표, 건강도시중점관리지표로 구성되어 있다. 그 기능은 크게 일반인과 관리자가 웹데이터베이스의 내용을 열람할 수 있도록 열람, 검색하는 기능을 주었는데 검색 기능은 데이터베이스를 구성하는 지표를 메 뉴로 대처하여 메뉴를 통해 찾아볼 수 있게 하였 다. 2009년 5월 현재 수집가능한 데이터까지 업데 이트하였다.

각종자료 $\mathrm{DB}$ 는 건강도시에 관련된 각종 내용을 대분류, 중분류, 소분류로 나누어 필요한 자료들을 찾아 볼 수 있도록 하였다. 예를 들어, 원하는 자 료를 받아보고자 할 경우에는 필요한 자료를 클릭 만 하면 웹상에서 바로 다운로드 받거나, 바로 열 어 볼 수 있도록 프로그래밍되어 있다. 건강도시지 표와 건강도시중점관리지표는 한글 외에 영어와 일어로도 제공하여 해외 교류 및 협력에 도움이 되도록 하였으며, 한글 지표에서 데이터를 업데이 트하면 영어 및 일어 지표에서 동일하게 표시되도 록 하였다<그림 2><그림 3>.

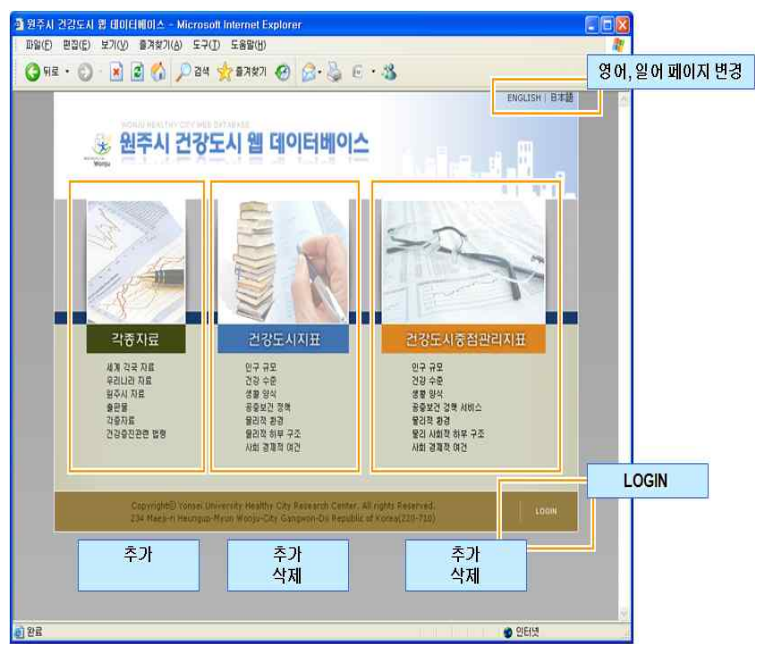

<그림 2> 메인화면의 영어, 일어 페이지 변경 및 Login 표시

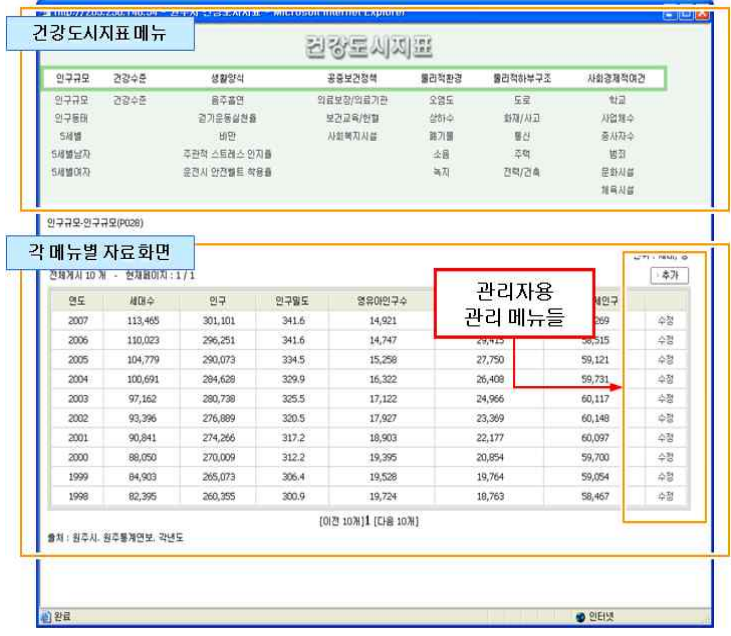

<그림 3> 건강도시지표 및 메뉴별 자료 화면

4. 사후조사 결과

1) 사후조사 응답자의 인구학적 특성

건강도시 데이터베이스 업데이트에 대한 사후조 사에 응답한 대상자의 인구학적 특성을 보면 다음 과 같다. 응답자의 연령별 분포를 살펴보면, 29 세 이하인 경우가 169 명 $(88.0 \%)$ 으로 대부분이었고, 30 세 이상인 경우는 23 명(11.9\%)에 불과하였다. 남자, 여자 각각 96 명 $(50.0 \%)$ 으로 동일하였다<표 $4>$.

<표 4> 사후조사 응답자의 인구학적 특성

\begin{tabular}{cccc}
\hline 분류 & 항목 & 명 & $\%$ \\
\hline \hline 연령 & 29세 이하 & 169 & 88.0 \\
& 30세 이상 & 23 & 11.9 \\
성별 & 남 & 96 & 50.0 \\
& 여 & 96 & 50.0 \\
\hline & 계 & 192 & 100.0 \\
\hline
\end{tabular}


2) 건강도시 데이터베이스에 대한 사후평가

원주 건강도시 데이터베이스 평가에 대한 문항 에서는 '제공된 데이터는 정확하다'에 '동의함'으로 응답한 경우가 126 명 $(65.6 \%)$, '어휘적 오류(오타 등)는 없다'에 134 명 $(69.8 \%)$ 이 응답하여 응답자의 절반 이상이 정확성에 대하여 긍정적으로 평가한 것으로 분석되었다. 또한 '데이터 제시가 일관적이 다'에 동의한 경우도 127 명 $(66.1 \%)$, '자료의 용어는 일관성이 있다'에는 129 명(67.2\%)이어서 일관성에
대하여도 긍정적으로 평가된 것으로 분석되었고, 이외에 포괄성과 권위에 대한 문항에 대하여도 절 반 이상이 '동의함'으로 응답하여 긍정적으로 평가 되었다. 그러나 '업데이트 주기는 적절하다'에서 '동의 못함'인 경우가 23 명(12.0\%), '제공된 자료는 다른 곳의 자료 보다 차별된 형태로 볼 수 있다'와 '다른 곳의 자료에서 찾을 수 없는 독특한 자료가 있다'에 동의하지 않은 경우가 각각 28 명(14.6\%), 24 명 $(12.5 \%)$ 이어서 최신성과 유일성에 대한 평가는 다른 문항에 비하여 다소 부정적이었다<표 5>.

<표 5> 원주시 건강도시 데이터베이스에 대한 사후평가 $(\mathrm{N}=192)$

\begin{tabular}{|c|c|c|c|c|}
\hline 영역 & 항목 & 동의못함 & 보통 & 동의함 \\
\hline \multirow[t]{2}{*}{ 정확성 } & 제공된 데이터는 정확하다. & $10(5.2)$ & 56(29.2) & $126(65.6)$ \\
\hline & 어휘적 오류(오타 등)는 없다. & $9(4.7)$ & $49(25.5)$ & $134(69.8)$ \\
\hline \multirow[t]{2}{*}{ 최신성 } & 가장 최근의 데이터로 제공되고 있다. & $24(12.5)$ & $53(27.6)$ & $115(59.9)$ \\
\hline & 업데이트 주기는 적절하다. & $23(12.0)$ & $83(43.2)$ & $86(44.8)$ \\
\hline \multirow[t]{2}{*}{ 일관성 } & 데이터 제시가 일관적이다. & $7(3.6)$ & $58(30.2)$ & $127(66.1)$ \\
\hline & 자료의 용어는 일관성이 있다. & $11(5.7)$ & $52(27.1)$ & $129(67.2)$ \\
\hline \multirow[t]{2}{*}{ 포괄성 } & 데이터의 내용 제공 범위는 적절하다. & $12(6.3)$ & $61(31.8)$ & $119(62.0)$ \\
\hline & 데이터의 제공 기간은 적절하다. & $15(7.8)$ & $66(34.4)$ & $111(57.8)$ \\
\hline \multirow[t]{2}{*}{ 권위 } & 제공된 자료의 출처가 명확하다. & $12(6.3)$ & $43(22.4)$ & $137(71.4)$ \\
\hline & 자료의 출처는 믿을 만한 곳이다. & $9(4.7)$ & $41(21.4)$ & $142(74.0)$ \\
\hline \multirow[t]{2}{*}{ 유일성 } & 제공된 자료는 다른 곳의 자료 보다 차별된 형태로 볼 수 있다. & $28(14.6)$ & $75(39.1)$ & $89(46.4)$ \\
\hline & 다른 곳의 자료에서 찾을 수 없는 독특한 자료가 있다. & $24(12.5)$ & $70(36.5)$ & $98(51.0)$ \\
\hline \multirow[t]{3}{*}{ 신속성 } & 전체 웹사이트의 로딩 속도는 적절하였다. & $60(31.3)$ & $55(28.6)$ & $77(40.1)$ \\
\hline & 건강도시지표별 이용 속도는 적절하였다. & $36(18.8)$ & $66(34.4)$ & $90(46.9)$ \\
\hline & 각종자료의 원문 다운로드 속도는 적절하였다. & $32(16.7)$ & $74(38.5)$ & $86(44.8)$ \\
\hline 사용 & 도움말 제공은 적절하였다. & $31(16.1)$ & $74(38.5)$ & $87(45.3)$ \\
\hline \multirow[t]{2}{*}{ 지원성 } & 피드백 기능은 적절하였다. & $30(15.6)$ & $77(40.1)$ & $85(44.3)$ \\
\hline & 기타 안내는 적절하였다. & $28(14.6)$ & $78(40.6)$ & $86(44.8)$ \\
\hline \multirow[t]{5}{*}{ 유형성 } & 화면 배색은 적절하였다. & $30(15.6)$ & $61(31.8)$ & $101(52.6)$ \\
\hline & 텍스트와 이미지의 구성 비율은 적절하였다. & $36(18.8)$ & $60(31.3)$ & $96(50.0)$ \\
\hline & 아이콘의 가시성이나 전달능력은 적절하였다. & $35(18.2)$ & $65(33.9)$ & $92(47.9)$ \\
\hline & 화면당 출력량은 적절하였다. & $30(15.6)$ & $57(29.7)$ & $105(54.7)$ \\
\hline & 화면당 데이터의 배열은 적절하였다. & $29(15.1)$ & $53(27.6)$ & $110(57.3)$ \\
\hline 이해 & 메뉴의 구성은 이해하기 쉬웠다. & $26(13.5)$ & $56(29.2)$ & $110(57.3)$ \\
\hline \multirow[t]{2}{*}{ 용이성 } & 화면에 나타나는 데이터는 이해하기 쉬웠다. & $28(14.6)$ & $72(37.5)$ & $92(47.9)$ \\
\hline & 사용하는 용어는 이해가 쉬웠다. & $23(12.0)$ & $73(38.0)$ & $96(50.0)$ \\
\hline 사용 & 산출물이 귀하가 원하는 형태로 제공되어 이용이 용이하였다. & $25(13.0)$ & $77(40.1)$ & $90(46.9)$ \\
\hline 용이성 & 귀하가 원하는 메뉴가 제공되어 자료검색 이용이 편리하였다. & 19(9.9) & $88(45.8)$ & $85(44.3)$ \\
\hline \multirow[t]{3}{*}{ 효과성 } & 건강도시DB가 원주시에 긍정적인 영향을 미칠 수 있다. & $11(5.7)$ & $53(27.6)$ & $128(66.7)$ \\
\hline & 건강도시DB가 건강도시사업에 긍정적인 영향을 줄 수 있다. & $6(3.1)$ & $48(25.0)$ & $138(71.9)$ \\
\hline & 건강도시DB에 전반적으로 만족한다. & 13(6.8) & $56(29.2)$ & $123(64.1)$ \\
\hline
\end{tabular}




\section{IV. 결론 및 제언}

\section{1. 결론}

건강도시 데이터베이스의 목적은 건강도시사업 담당자, 보건소 직원은 물론 시민과 여러 분야의 관련자가 정확한 정보를 공유할 수 있도록 하는데 있다. 이번 데이터베이스 업데이트를 통하여 건강 도시지표 및 자료를 보다 편리하게 관리할 수 있 도록 하여, 최신 정보를 신속히 제공하고, 건강도 시사업의 성과를 보다 용이하게 평가할 수 있게 되었다.

건강도시 웹데이터베이스 업데이트를 통하여 건 강도시사업의 성과를 평가할 수 있는 지표의 실제 적 활용도를 높임으로써, 연도별 건강도시사업의 성과를 일목요연하게 알 수 있게 되었다. 이번 2009년 원주시 데이터베이스 제 2판(2009년)은 매 년 데이터 생산이 되고 있으며, 데이터에 대한 접 근이 용이하고, 전국 비교가 가능하며, 원주시 통 계연보 및 지역사회건강조사에서 주기적으로 제공 될 수 있는 지표를 중심으로 8개 영역 29개 지표 로 건강도시중점관리지표를 변경하였다. 변경된 주 된 이유는 건강도시지표 생성에 어려움이 있었기 때문이다. 또한 기존 지표를 건강도시사업에 유용 한 지표로 변경하고, 최근 건강도시와 관련하여 중 요성이 커지고 있는 지표를 추가하였다.

추가한 내용에 대한 사후평가에서, 데이터베이 스에서 제공된 자료의 출처가 명확하고, 신뢰성이 있는 것으로, 데이터베이스가 건강도시사업에 긍정 적인 영향을 줄 것이라는 평가가 많았다. 웹데이터 베이스 업데이트는 이전 제 1판(2006년)에서 구성 된 윕데이터베이스의 기술적 기본골격은 가능한 유지하여 개발에 소요되는 비용을 절감함과 동시 에 이용자들의 편의성과 유용성을 증진 시킬 수 있도록 하였다. 또한 데이터베이스의 콘텐츠의 보 강이란 측면에서 새로운 건강도시 관련 자료 획득
에 대한 가능성을 충분히 반영하기 위한 항목의 추가, 변경, 삭제되는 변경을 시도하였다. 또한 원 주시에서 건강도시 데이터베이스를 직접 손쉽게 업데이트 및 관리할 수 있도록 관리 시스템을 변 경하였다. 그 결과, 이제는 원주시 건강도시 데이 터베이스 담당자가 데이터 및 자료를 쉽게 추가, 변경, 삭제할 수 있게 되었다.

2. 제언

연구결과에 근거하여 다음과 같이 몇 가지 제언 을 하고자 한다.

첫째, 이후에도 건강도시 데이터베이스를 지속 적으로 업데이트하여야 하며, 최소 1 년 단위로 최 신 자료를 추가하고, 국내외 다른 건강도시 데이터 베이스와 연계하는 방안을 고려하여야 한다. 또한 데이터베이스 이용자의 요구사항을 계속 수렴하고, 이에 따른 보완도 지속적으로 이루어져야 한다.

둘째, 관련 통계 자료의 보완을 통한 다양한 건 강도시지표의 모니터링이 요구된다. 효율적인 건강 도시사업의 수행, 관리, 평가를 위해서는 필요로 하는 기본적인 정보가 통계로 제공되어야 한다. 그 러나 아직도 많은 정보가 통계자료로 생산되지 못 하여 제공되지 못하는 부분들이 있으며, 관련 정보 가 제공되는 경우에도 부정확한 통계가 제시되는 경우가 종종 있다. 시계열적인 자료의 비교나 다른 지역과의 비교를 위해서도 이러한 부분은 개선이 요구되는 주요한 부분이라고 할 수 있다.

셋째, 원주시가 추진하고 있는 U-Health 운동사 업과 연계하면 원주시의 최신 건강관리 데이터를 신속히 확보할 수 있을 것이다. 이를 통해 단말기 보급 주민에 대한 지역별 운동 및 건강관리상태 통계를 얻어 상황에 따른 보다 빠른 대처가 가능 해질 수 있다.

넷째, 전국 지방자치단체별 데이터를 확보할 수 
있는, 건강도시지표 데이터베이스가 구축된다면 건 강도시사업의 수행 및 평가가 보다 효율적일 것이 다. 한국에서는 2010년 현재 약 50 개의 지방자치단 체가 대한민국건강도시협의회의 회원으로 건강도 시사업을 활발히 추진하고 있다. 이제 그동안의 사 업에 대한 평가를 바탕으로 향후 사업에 대한 기 획이 필요한 이 시점에서 건강도시지표 데이터베 이스 구축을 통한 근거중심의 건강도시사업은 사 업의 평가 및 향후계획에 실제적인 도움을 줄 수 있을 것으로 기대된다.

\section{참고문헌}

1. 김건엽(2005), 건강도시 금산 프로젝트 연구보고서 -건강도시 지표개발을 위한 지역사회 현황분석, p.25.

2. 김춘배 외 11 명(2002), 지역사회보건관련 데이터베 이스 구축에 따른 소지역간 건강증진지표 개발, 연세대학교·보건복지부, p.86.

3. 남은우, 박재성, 송예리아(2006), 건강도시지표 비 교를 통한 건강도시 수준의 평가, 보건행정학회지, Vol.16(2);1-20.

4. 남은우, 박재성, 송예리아(2005), 원주시 건강도시 지표 비교 연구, 원주시·연세대학교 건강도시연 구센터, p.60.

5. 박미영, 승현우(2006), 데이터베이스 품질 평가를 위한 품질 특성 정의 및 선정, 정보기술논문지, Vol.4;13-21.

6. 박재경, 구상진, 이승욱, 김유정(1997), 보건의료정 보의 데이터베이스구축과 $\mathrm{Web}$ 상에서의 정보제공 시스템개발, 국민보건연구소 연구논총, $\operatorname{Vol} .7(2) ; 19$ -25 .

7. 송태민, 류시원, 박대순, 고혜연, 강성원(2009), 보 건복지가족부 웹 사이트 통합.연계 및 발전방안 연구, 한국보건사회연구원, pp.1-201.

8. 정혜명(2004), 학교보건 증진을 위한 데이터베이스
의 개발 및 관리, 한국보건간호학회지, Vol.18(1);154-166.

9. 최정명, 이혜자, 김춘미(2004), 보건소 건강증진사 업을 위한 데이터베이스 시스템 구축: 고혈압과 갱년기 여성건강관리를 중심으로,지역사회간호학 회지, Vol.15(3);365-375.

10. 홍현진(2005), 웹 기반 데이터베이스의 품질평가 기준 개발에 관한 연구, 한국문헌정보학회지, Vol.39(2);211-235.

11. Miller R(2008), Twelve Point Plan For Quantitative and Qualitative Evaluation of Databases.Preview, Computers in Libraries, Vol.28(7);S2-S3.

12. WHO(1998), City Health Profiles: How to report on health in your city.

사례연구 접수일자 2011년 12월 13일 사례연구 심사일자 2011년 12월 20일 사례연구 게재확정일자 2012년 1월 15일 